\title{
Regulation and Characterization of Acid and Alkaline Phosphatase in Yeast
}

\author{
By A. SCHURR* AND E. YAGIL \\ Department of Biochemistry, Tel-Aviv University, \\ Tel-Aviv, Israel \\ (Accepted for publication 4 January I97I)
}

\begin{abstract}
SUMMARY
The activity of acid and alkaline phosphatase in baker's yeast is derepressed when the organisms are starved of phosphate. Mutants lacking phosphatase activity and mutants with constitutive phosphatase synthesis were isolated. In all of them acid and alkaline phosphatases were affected simultaneously. Nevertheless, characterization of these two enzymes by sensitivity to inhibition by orthophosphate, temperature inactivation, proteolytic digestion and cation dependence showed that they were clearly distinct. It is suggested that these two enzymes share a common genetic and structural component.
\end{abstract}

\section{INTRODUCTION}

The regulation of non-specific phosphomonoesterase (phosphatase) activity by the concentration of orthophosphate in the culture medium has been reported in several organisms. These include Escherichia coli (Torriani, 1960), Bacillus subtilis (Fan, I966; Moses, 1967), Neurospora crassa (Nyc, Kadner \& Crocken, 1966), Aspergillus (Dorn, 1965; Dorn \& Rivera, 1966; Shieh, Wodzinski, \& Ware, 1969), Euglena (Blum, I965; Bennun \& Blum, 1966), Torulopsis utilis (Rautanen \& Kärkkäinen, 195I) and Saccharomyces cerevisiae (Suomalainen, Linko \& Oura, 1960; Schmidt et al. I963). The best understood of these regulatory systems is that of alkaline phosphatase in $E$. coli, in which it was clearly demonstrated that the derepression of enzyme activity caused by phosphate starvation is due to de novo enzyme synthesis (Garen \& Levinthal, I960); one structural and two regulatory loci were characterized and mapped (Echols, Garen, Garen \& Torriani, 196r; Aono \& Otsuji, 1968; Bracha \& Yagil, 1969).

Two non-specific phosphomonoesterases-acid and alkaline phosphatase (EC 3.I.3.2 and EC 3.I.3.I, respectively) - are known to occur in baker's yeast (Saccharomyces cerevisiae). These two phosphatases differ both in their optimum $\mathrm{pH}$ activity and their cellular location, and their activity is derepressed upon phosphate starvation (Suomalainen et al. 1960; McLellan \& Lampen, 1963; Schmidt et al. 1963; Tonino \& Steyn-Parvé, 1963). No information is as yet available on the genetic aspects of this regulatory system. In this paper we describe the isolation of mutants impaired either in phosphatase activity or in the regulation of phosphatase synthesis. In all mutants isolated both acid and alkaline phosphatases were affected simultaneously and we therefore determined whether these two enzymes differed with respect to several other properties.

\footnotetext{
* Present address: Negev Institute for Arid Zone Research, Beer-Sheva, Israel.
} 


\section{METHODS}

Organisms. (Abbreviations used: $l e u=$ leucine, his $=$ histidine, met $=$ methionine, $c a n-r=$ resistance to canavanine.) The strains of Saccharomyces cerevisiae used in this study were $\mathrm{s} 288 \mathrm{C}$ (mating type $\alpha$ ), and three of its derivatives: X2I80-I A (mating type a), s878c leu, his 7 (mating type $\alpha$ ) and EY 9 met 8 can-r (mating type a). All were obtained from Professor R. K. Mortimer.

\section{Media}

YEPD medium. A rich medium used for plating. It contained per litre: Io g. yeast extract, $20 \mathrm{~g}$. Bacto peptone (Difco), $20 \mathrm{~g}$. dextrose, $20 \mathrm{~g}$. agar.

Minimal medium. A modification of the medium described by Kitazume, Yčas \& Vincent (1962) was used for both liquid cultures and for plating. One litre $0.02 \mathrm{M}-$ citrate buffer ( $\mathrm{pH} 5.0$ ) contained: 2 g. $\mathrm{NH}_{4} \mathrm{Cl}, 0.5 \mathrm{~g} . \mathrm{MgSO}_{4} \cdot 7 \mathrm{H}_{2} \mathrm{O}, 0.3 \mathrm{~g} . \mathrm{CaCl}_{2}$, o. I g. KCl, $30 \mathrm{~g}$. glucose, $50 \mathrm{mg}$. DL-asparagine, $60 \mathrm{mg}$. inositol, $6 \mathrm{mg}$. thiamine- $\mathrm{HCl}$, I mg. pyridoxine, $0.15 \mathrm{mg}$. biotin, $0.5 \mathrm{mg}$. Ca-pantothenate, $0.5 \mathrm{mg}$. citric acid. $\mathrm{IH}_{2} \mathrm{O}$, $0.5 \mathrm{mg}$. $\mathrm{ZnSO}_{4} \cdot 7 \mathrm{H}_{2} \mathrm{O}, 0 . \mathrm{I} \mathrm{mg}$. $\mathrm{Fe}\left(\mathrm{NH}_{4}\right)_{2}\left(\mathrm{SO}_{4}\right)_{2} \cdot 6 \mathrm{H}_{2} \mathrm{O}, 25 \mu \mathrm{g} . \mathrm{CuSO}_{4} \cdot 5 \mathrm{H}_{2} \mathrm{O}, 5 \mu \mathrm{g}$. $\mathrm{MnSO}_{4} \cdot \mathrm{IH}_{2} \mathrm{O}, 5 \mu \mathrm{g} . \mathrm{H}_{3} \mathrm{BO}_{3}, 5 \mu \mathrm{g}$. $\mathrm{Na}_{2} \mathrm{MoO}_{4} \cdot 2 \mathrm{H}_{2} \mathrm{O}$. Where necessary, $60 \mathrm{mg}$. Lleucine, $40 \mathrm{mg}$. DL-histidine or $20 \mathrm{mg}$. L-methionine/l. were added. For plating, agar at $2 \%$ was added. This minimal medium was supplemented with $\mathrm{KH}_{2} \mathrm{PO}_{4}$ as follows: High-Pi minimal medium, $0.4 \mathrm{~g}$. $\mathrm{KH}_{2} \mathrm{PO}_{4} / 1$. (3 mM); Low-Pi minimal medium, $0.05 \mathrm{~g}$. $\mathrm{KH}_{2} \mathrm{PO}_{4} / 1$. (0.37 mM) (used only for plating); No-Pi minimal medium, no added phosphate.

Growth conditions. The strains were maintained in YEPD slants. Organisms from a single colony were grown overnight in a reciprocating shaker water-bath (Tutenauer, Jerusalem, Israel) at $30^{\circ}$, in a minimal medium containing a limiting concentration of glucose $(0.8 \mathrm{~g} . / 1$.). At this concentration the culture reached an absorbancy (recorded in a Zeiss PMQ II spectrophotometer at $440 \mathrm{~nm}$.) of approximately unity ( $\sim 10^{8}$ organisms $/ \mathrm{ml}$.). The next morning the organisms were diluted into a fresh minimal medium to resume exponential growth (generation time of 140 to $150 \mathrm{~min}$.). Growth was followed by the change in extinction at $440 \mathrm{~nm}$. $\left(E_{440}\right)$. Dilutions for viable counts were carried out in $0.02 \mathrm{M}$-citrate buffer $\left(\mathrm{pH} 5^{\circ} 0\right)$.

Preparation of organisms for enzymic assays. Unless otherwise indicated all assays were carried out with enzyme prepared from strain s $288 \mathrm{C}$ grown for $24 \mathrm{~h}$. in No-Pi minimal medium. The samples taken from the growth medium were centrifuged,washed once and resuspended in the appropriate buffer ( $\mathrm{O} \cdot \mathrm{I}$ M-acetate buffer, $\mathrm{pH} 3.65$, for acid phosphatase and $\mathrm{O} \cdot \mathrm{I} \mathrm{M}$-tris-chloride buffer, $\mathrm{pH} \mathrm{8.9}$, containing $\mathrm{IO}^{-3} \mathrm{M}_{-} \mathrm{MgSO}_{4}$ for alkaline phosphatase). For cell disruption $8 \mathrm{~g}$. of glass beads $(0.25$ to $0.30 \mathrm{~mm}$. diameter size) were added to $\mathrm{I} 0 \mathrm{ml}$. of the suspension, which was then shaken for $3 \mathrm{~min}$. in a Braun mechanical cell homogenizer (model MSK, type 2376). In preliminary experiments using various sizes of glass beads and different shaking times these conditions proved to be optimum for maximal enzyme recovery.

Mixed enzyme preparation. In some of the experiments the enzyme assay was performed in a mixture $(\mathrm{v} / \mathrm{v})$ of a supernatant of cells disrupted in $\mathrm{O} \cdot \mathrm{I}$ M-acetate buffer with a supernatant of cells disrupted in O.I M-tris-Mg buffer; the mixture had a final $\mathrm{pH}$ of 6 . This procedure preserved most of the acid and alkaline phosphatase activity. Assay of acid phosphatase. The activity of acid phosphatase is located on the outer 
cell surface (McLellan \& Lampen, 1963; Schmidt et al. 1963; Tonino \& Steyn-Parvé, 1963). The enzyme assay was carried out either with a suspension of intact cells or with the supernatant of disrupted cells. The reaction mixture, in a final volume of $2 \mathrm{ml}$,, contained $\mathrm{I} \cdot 9 \mathrm{ml}$. $p$-nitrophenyl phosphate (NPP, $0.8 \mathrm{mg}$./ml.) dissolved in $0 . \mathrm{I} \mathrm{M}$ acetate buffer and $0.1 \mathrm{ml}$. enzyme solution. After incubation for 5 to $25 \mathrm{~min}$. at $37^{\circ}$ the reaction was terminated with $0.5 \mathrm{ml}$. I $\mathrm{M}-\mathrm{NaOH}$, the mixture centrifuged when necessary and the extinction read at $4 \mathrm{IO} \mathrm{nm}$. The yellow colour of the liberated $p$-nitrophenol is only apparent at alkaline pH. One enzyme unit (e.u.) is defined as the amount of enzyme catalysing the liberation of I $\mu$ mole nitrophenol $/ \mathrm{min}$. Fig. I shows the linearity of the reaction as a function either of time (Fig. I $a$ ) or dilution (Fig. I $b$ ) when a suspension of intact organisms was assayed.

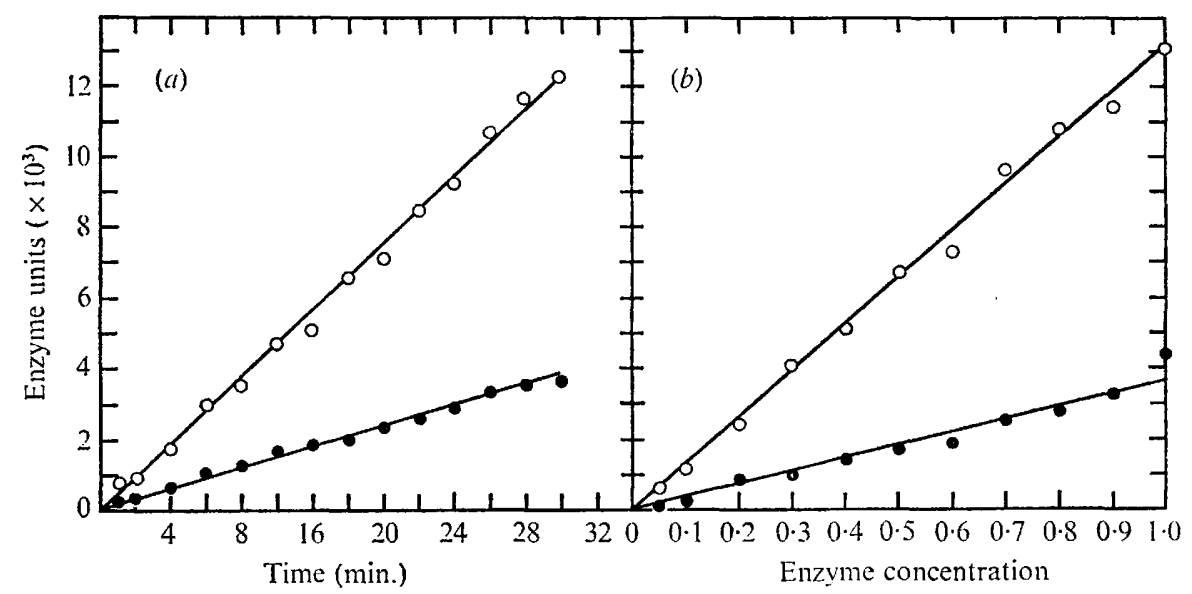

Fig. I. The activity of acid phosphatase $(O)$ and alkaline phosphatase $(\bullet)$ as a function of time (a) or dilution $(b)$. Acid phosphatase was determined in a suspension of whole organisms and alkaline phosphatase in a suspension of disrupted organisms. Enzyme concentration defined as unity $(b)$ is the amount of enzyme extracted from a culture of approximately $5 \times 10^{7}$ organisms $/ \mathrm{ml}$; ; serial dilutions of this enzyme were assayed.

Assay of alkaline phosphatase. The activity of this enzyme is internally located (Tonino \& Steyn-Parvé, 1963) and the assay was carried out either with a suspension or with the supernatant of disrupted organisms. The reaction mixture was the same as for acid phosphatase except that the substrate (NPP) was dissolved in I M-trischloride buffer, $\mathrm{pH} 8.9$, and the reaction stopped with $0.5 \mathrm{ml} .5 \mathrm{M}-\mathrm{NaOH}$. Enzyme units are as for acid phosphatase. Fig. I shows the linearity of the reaction as a function either of time (Fig. I $a$ ) or dilution (Fig. I $b$ ) when a suspension of disrupted organisms was assayed.

Determination of phosphatase activity in colonies. A modification of the method used for colonies of Aspergillus and Escherichia coli (Dorn, 1965; Bracha \& Yagil, 1969) was used. Plates were sprayed with a mixture of equal volumes of $\alpha$-naphtyl phosphate (I mg./ml., Calbiochem) and tetrazotized-o-dianizidine $(5 \mathrm{mg} . / \mathrm{ml}$. , Sigma). Both compounds were dissolved in $0 . \mathrm{I}$ M-acetate buffer at $\mathrm{pH} 3.65$. Dark-purple coloration of the colony indicated phosphatase activity.

Mutagenesis by ethylmethane sulphonate (EMS). The treatment was carried out as 
described by Lindegren, Hwang, Oshima \& Lindegren (1965). The treated organisms were centrifuged, resuspended in $0.02 \mathrm{M}$-citrate buffer $\left(\mathrm{pH}^{\circ}{ }^{\circ}\right)$ and plated on High-Pi and on Low-Pi minimal medium.

Chemicals. $p$-Nitrophenyl phosphate, $\alpha$-naphtyl phosphate and pronase were obtained from Calbiochem, tetrazotized-o-dianizidine from Sigma, ethylmethane sulphonate from Koch-Light, ethylene diaminetetraacetate (EDTA) from Merck, I,IO-phenanthroline from Eastman Organic Chemicals and 8-hydroxyquinoline from British Drug Houses.

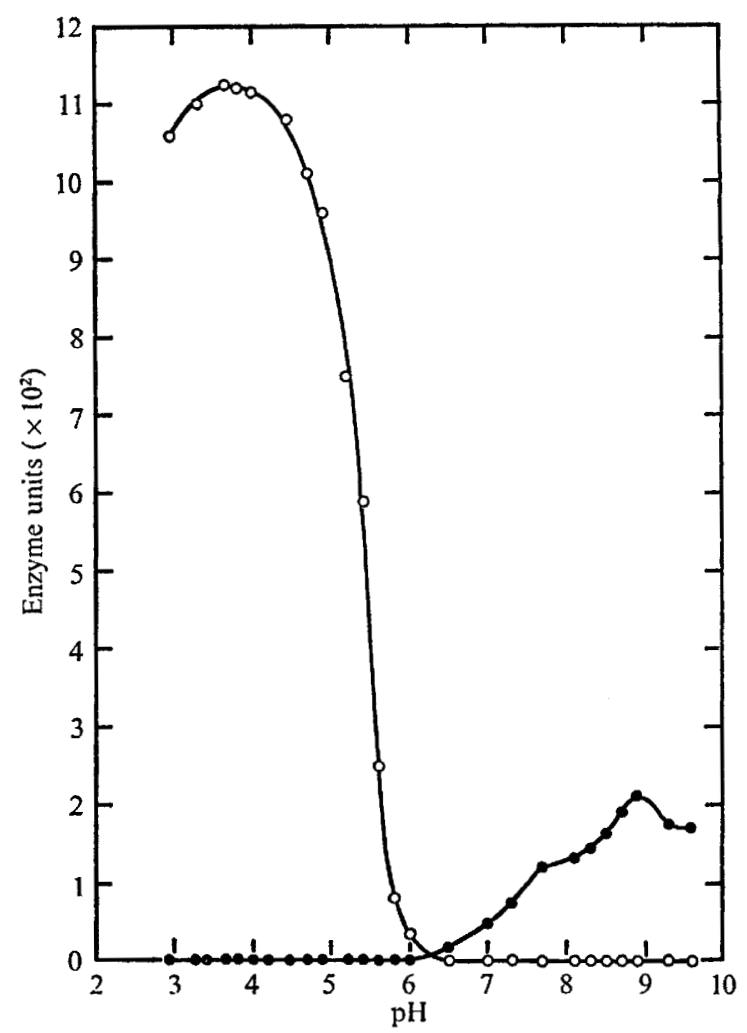

Fig. 2. Effect of $\mathrm{pH}$ on phosphatase activity. Derepressed organisms were centrifuged and resuspended either in 0.1 M-acetate buffer $(\mathrm{pH} 4)$ or in $0^{\circ} \mathrm{I}$ M-tris-Mg buffer $(\mathrm{pH} 8)$. The two suspensions were disrupted and acid phosphatase $(O)$ and alkaline phosphatase $(0)$ deterined at the appropriate $\mathrm{pH}$; for $\mathrm{pH} 2.95$ to $6.50 . \mathrm{I} \mathrm{M}$-acetate buffer was used, and for $\mathrm{pH} 7.0$ to $9 \cdot 60 \cdot \mathrm{I}$ M-tris- $\mathrm{HCl}$ buffer was used.

\section{RESULTS}

\section{Effect of $p H$ on phosphatase activity}

Organisms were grown in minimal medium under conditions of phosphate starvation which derepress the phosphatases (see below). The organisms were disrupted either in $0.1 \mathrm{M}$-acetate buffer $(\mathrm{pH} 5)$ or in tris- $\mathrm{Mg}$ buffer $(\mathrm{pH} 8)$ and the activity of each supernatant determined over a $\mathrm{pH}$ range of 2.95 to 9.6 (Fig. 2). The two optima, one at $\mathrm{pH}_{3} .65$ and the other at $\mathrm{pH} \mathrm{8.9,} \mathrm{represent} \mathrm{the} \mathrm{activity} \mathrm{of} \mathrm{acid} \mathrm{phosphatase}$ and alkaline phosphatase respectively. Suomalainen $e$ t al. (1960) reported equivalent 
$\mathrm{pH}$ optima of 4.4 and 7.9 to 8.9 , and Tonino \& Steyn-Parvé (1963) 3 to 4 and 9 to 10. The activity of acid phosphatase is approximately five times greater than that of alkaline phosphatase. In other experiments an even greater difference was obtained.

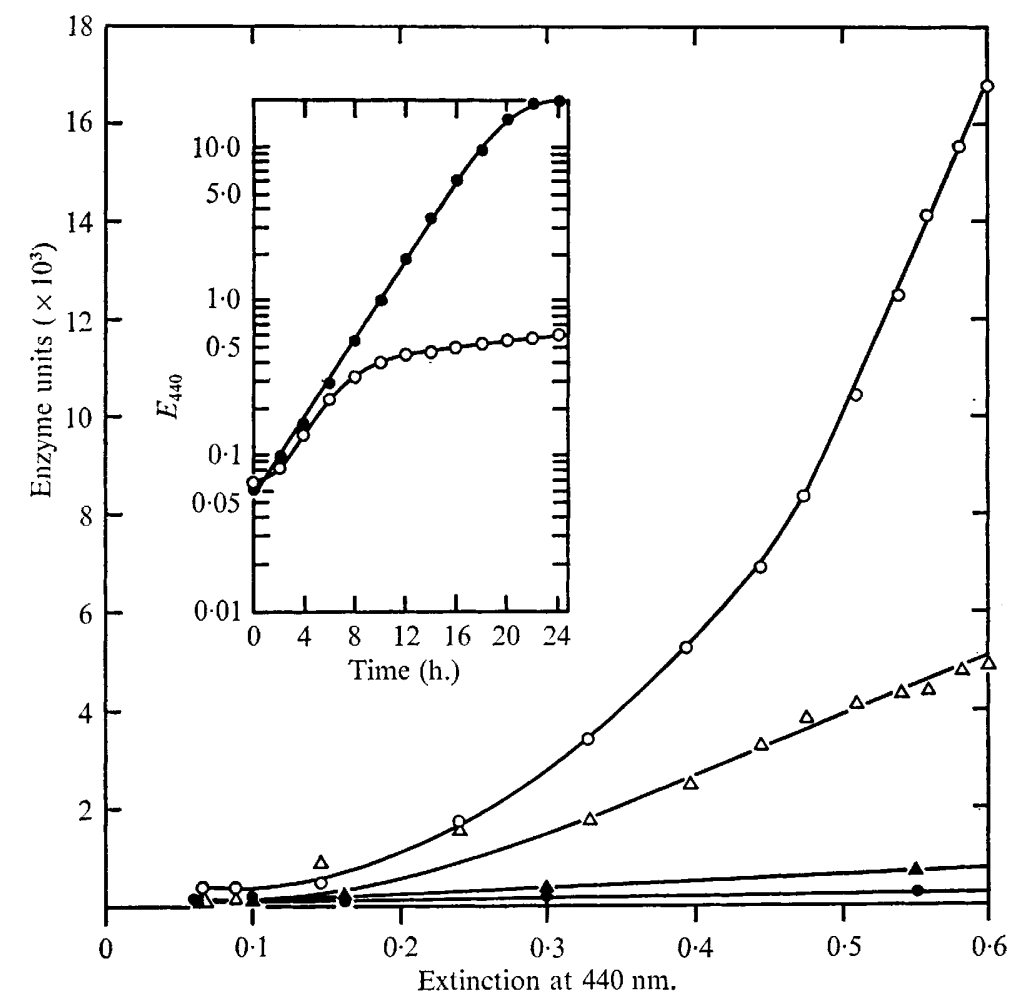

Fig. 3. Derepression of phosphatase by phosphate starvation. Organisms growing exponentially in minimal medium were washed and resuspended either in High-Pi medium (closed symbols) or in No-Pi medium (open symbols). Following resuspension, samples were removed at intervals of $2 \mathrm{~h}$. for the determination of growth (insert) and of acid $(\mathrm{O}, \boldsymbol{\bullet})$ and of alkaline phosphatase $(\triangle, \Delta)$. Enzyme activity is expressed as a function of growth.

\section{Table I. Effect of phosphate in the culture medium on acid and}

$$
\text { alkaline phosphatase activity }
$$

Organisms were grown for $24 \mathrm{~h}$. in minimal medium containing $\mathrm{KH}_{2} \mathrm{PO}_{4}$ at the indicated concentration and the enzyme activity determined. Specific activity is expressed as e.u./ $E_{440}$.

$\begin{array}{ccc}\begin{array}{c}\text { Concentration } \\ \text { of } \mathrm{KH}_{2} \mathrm{PO}_{4} \\ (\mathrm{mM})\end{array} & \begin{array}{c}\text { Acid } \\ \text { phosphatase } \\ \left(\text { sp. act. } \times 10^{3}\right)\end{array} & \begin{array}{c}\text { Alkaline } \\ \text { phosphatase } \\ \left(\text { sp. act. } \times 10^{3}\right)\end{array} \\ 0 & 2.23 & 0.48 \\ 0.25 & 0.36 & 0.40 \\ 0.5 & 0.21 & 0.33 \\ 1.0 & 0.34 & 0.17 \\ 2.0 & 0.16 & 0.17 \\ 5.0 & 0.19 & 0.15\end{array}$




\section{Regulation of phosphatase activity in the culture}

Table I shows the enzyme activity of acid and alkaline phosphatases in cultures grown for $24 \mathrm{~h}$. in minimal medium with various concentrations of phosphate. The response of acid phosphatase to regulation by phosphate is much more marked than that of alkaline phosphatase. Under phosphate starvation acid phosphatase becomes derepressed by a factor of approximately $\mathrm{I} 2$ and at $0.25 \mathrm{mM}-\mathrm{KH}_{2} \mathrm{PO}_{4}$ it is almost completely repressed. Alkaline phosphatase is only derepressed by a factor of 3 and approaches maximum repression at $\mathrm{I} \mathrm{mM}-\mathrm{KH}_{2} \mathrm{PO}_{4}$. Under maximum repression both enzymes show the same basal level activity.

Fig. 3 shows the kinetics of derepression of both phosphatases when a culture is resuspended either in No-Pi or High-Pi minimal medium. The data are presented as differential rate curves, i.e. enzyme activity as a function of growth (cf. Monod, Pappenheimer \& Cohen-Bazire, 1952). In the phosphate-free culture acid phosphatase activity is markedly derepressed and reaches a steady state after approximately three generations of growth, at which time the growth of the culture slows down markedly due to lack of inorganic phosphate (Fig. 3, insert). The activity of alkaline phosphatase, which is derepressed to a lesser extent, seems to reach a steady state much earlier.

\section{Structural and constitutive mutants for phosphatase synthesis}

When wild-type yeast organisms are plated on Low-Pi ( $0.37 \mathrm{mM})$ minimal medium there is sufficient phosphate to permit growth of colonies, but due to exhaustion of phosphate the activity of phosphatase becomes derepressed. When sprayed for phosphatase activity wild-type repressible colonies are stained on Low-Pi plates and remain unstained on High-Pi plates. Mutants which have lost the capacity to synthesize active enzyme should not stain on either plate whereas constitutive mutants, in which enzyme synthesis is unaffected by the concentration of phosphate, should stain on both Low-Pi and High-Pi plates.

Wild-type organisms were treated with EMS and plated on either Low-Pi or HighPi media. Surviving colonies were sprayed and those which did not stain on Low-Pi plates were suspected of being structural and those staining on High-Pi constitutive mutants. Eight out of 953 colonies growing on Low-Pi plates did not show enzyme activity and 13 out of 942 colonies growing on High-Pi were enzymically active. The enzyme assays of three structural mutants $\left(\mathrm{PhoA}^{-}\right)$shows that activity is either lost completely $\left(\mathrm{PhoA}^{-} \mathrm{I}\right)$ or partially $\left(\mathrm{PhoA}^{-} 57, \mathrm{PhoA}^{-67}\right)$, but in all mutants isolated so far the activity of both acid and alkaline phosphatase is affected (Table 2). The constitutive mutants $\left(\mathrm{PhoR}^{-}\right)$show a high enzymic activity in the presence of phosphate. In some of them the activity is completely independent of phosphate ( $\mathrm{PhoR}^{-}{ }^{-5}$ ) and in others it is partially repressed ( $\mathrm{PhoR}^{-29}$, $\mathrm{PhoR}^{-3}$ - $)$. Also in the constitutive mutants both acid and alkaline phosphatase are affected. Furthermore, it may be noticed that the enzyme activity of the constitutive mutants is greater than in the wildtype derepressed cultures (Table 2). This is probably because phosphate starvation in the latter, which is required for derepression, is incomplete (Markham \& Byrne, I968). Full expression of the gene(s) involved is therefore prevented in the wild-type strains.

In all mutants tested, phosphatase-negative as well as constitutive, the activity of both enzymes was affected simultaneously. These results suggested that the two enzymes have structural as well as regulatory gene(s) in common. If this is so, in what ways do 
these two enzymes differ? It has already been established that they are located differently in the cells and have different $\mathrm{pH}$ optima for maximum activity. The rest of the experiments to be described establish that these two enzymes also differ in other properties.

\section{Table 2. Phosphatase activity in structural and constitutive mutants and their wild-type parental strains}

The cultures were grown for $\mathbf{2 4} \mathrm{h}$. in either No-Pi or in High-Pi minimal medium before the enzyme activity was assayed. Specific activity is expressed as e.u./E $\mathbf{4 6 0}$.

\begin{tabular}{|c|c|c|c|c|c|c|c|}
\hline \multirow[b]{2}{*}{ Strain } & \multirow[b]{2}{*}{$\begin{array}{c}\text { Mating } \\
\text { type }\end{array}$} & \multirow[b]{2}{*}{ Phenotype* } & \multirow[b]{2}{*}{ Medium } & \multicolumn{2}{|c|}{ Acid phosphatase } & \multicolumn{2}{|c|}{ Alkaline phosphatase } \\
\hline & & & & $\begin{array}{l}\text { Sp. act. } \\
\left(\times \mathrm{IO}^{3}\right)\end{array}$ & $\begin{array}{l}\text { Induction } \\
\text { ratio }\end{array}$ & $\begin{array}{l}\text { Sp. act. } \\
\left(\times 10^{3}\right)\end{array}$ & $\begin{array}{l}\text { Induction } \\
\text { ratio }\end{array}$ \\
\hline$X-2180-1 A$ & $\mathrm{a}$ & + & $\begin{array}{l}\text { No-Pi } \\
\text { High-Pi }\end{array}$ & $\begin{array}{l}2 \cdot 48 \\
0 \cdot 29\end{array}$ & $8 \cdot 4$ & $\begin{array}{l}0.93 \\
0.28\end{array}$ & $3 \cdot 3$ \\
\hline \multirow{3}{*}{$\mathrm{s} 878 \mathrm{C}$} & \multirow{3}{*}{ a } & $\mathrm{PhoA}^{-1} \mathrm{I}$ & $\left.\begin{array}{l}\text { No-Pi } \\
\text { High-Pi }\end{array}\right\}$ & 0 & - & 0 & - \\
\hline & & + & $\begin{array}{l}\text { No-Pi } \\
\text { High-Pi }\end{array}$ & $\begin{array}{l}3 \cdot 88 \\
0 \cdot 37\end{array}$ & $10 \cdot 5$ & $\begin{array}{l}0.55 \\
0.12\end{array}$ & $4 \cdot 6$ \\
\hline & & $\mathrm{PhoA}^{-} 57$ & $\begin{array}{l}\text { No-Pi } \\
\text { High-Pi }\end{array}$ & $\begin{array}{l}0.04 \\
0.06\end{array}$ & 0.7 & $\begin{array}{l}0.07 \\
0.06\end{array}$ & $\mathrm{I} \cdot \mathbf{2}$ \\
\hline \multirow{5}{*}{ EY9 } & \multirow{5}{*}{$\alpha$} & PhoR-29 & $\begin{array}{l}\text { No-Pi } \\
\text { High-Pi }\end{array}$ & $\begin{array}{r}12 \cdot 60 \\
9 \cdot 70\end{array}$ & $\mathbf{I} \cdot \mathbf{3}$ & $\begin{array}{l}0.80 \\
0.65\end{array}$ & $I \cdot 2$ \\
\hline & & $\mathrm{PhoR}^{-} 3 \mathrm{I}$ & $\begin{array}{l}\text { No-Pi } \\
\text { High-Pi }\end{array}$ & $\begin{array}{l}6 \cdot 70 \\
3.27\end{array}$ & $2 \cdot 0$ & $\begin{array}{l}0.43 \\
0.24\end{array}$ & $\mathrm{I} \cdot 8$ \\
\hline & & + & $\begin{array}{l}\text { No-Pi } \\
\text { High-Pi }\end{array}$ & $\begin{array}{l}2 \cdot 20 \\
0 \cdot 23\end{array}$ & $9 \cdot 5$ & $\begin{array}{l}0.44 \\
0.09\end{array}$ & $4 \cdot 9$ \\
\hline & & $\begin{array}{l}\text { PhoA-67 } \\
\text { (leaky) }\end{array}$ & $\begin{array}{l}\text { No-Pi } \\
\text { High-Pi }\end{array}$ & $\begin{array}{l}0.97 \\
0.27\end{array}$ & $3 \cdot 6$ & $\begin{array}{l}0.15 \\
0.08\end{array}$ & $I \cdot 9$ \\
\hline & & PhoR-54 & $\begin{array}{l}\text { No-Pi } \\
\text { High-Pi }\end{array}$ & $\begin{array}{l}15 \cdot 80 \\
15 \cdot 10\end{array}$ & $\mathrm{I} \cdot \mathrm{O}$ & $\begin{array}{l}I \cdot 73 \\
I \cdot 52\end{array}$ & $I \cdot I$ \\
\hline
\end{tabular}

* $\mathrm{PhoA}^{-} \mathrm{I}=$ phosphatase-negative, isolation number $\mathrm{I}$; $\mathrm{PhoR}^{-29}=$ phosphatase-constitutive, isolation number 29 .

Inhibition by orthophosphate and the reaction velocity

The activity of alkaline phosphatase of Escherichia coli and Aspergillus is inhibited competitively by orthophosphate (Torriani, 1960; Dorn, 1968; Shieh et al. 1969; Simpson \& Vallee, 1969) as is the activity of acid phosphatase from Euglena (Bennun \& Blum, 1966) and Neurospora (Nyc et al. 1966). The activity of acid phosphatase is strongly inhibited by $\mathrm{K}_{2} \mathrm{HPO}_{4}$ while that of alkaline phosphatase is almost unaffected; at $\mathrm{IO}^{-2} \mathrm{M}$ only $15 \%$ of acid phosphatase remained active whereas alkaline phosphatase retained $75 \%$ of its activity (Fig. 4). Fig. $5(a, b)$ shows the reaction velocity of acid and alkaline phosphatase, as a function of substrate ( $p$-nitrophenyl-phosphate) concentration at three concentrations of phosphate. The reaction kinetics of acid phosphatase (Fig. $5 a$ ) show inhibition by the product (phosphate) liberated during the reaction. Alkaline phosphatase (Fig. $5 b$ ) is much less inhibited by phosphate. Lineweaver-Burk plots of data from Fig. 5(a,b) are shown in Fig. 5(c); the $K_{m}$ value of both enzymes is $4.5 \times 10^{-4} \mathrm{M}$. A $K_{m}$ value of $5.3 \times 10^{-4} \mathrm{M}$ was reported for acid phosphatase by Boer \& Steyn-Parvé (1969). $\mathrm{K}_{2} \mathrm{HPO}_{4}$ proves to be a competitive inhibitor of acid phosphatase with a $K_{i}$ value of $\mathrm{I} \cdot 36 \times 10^{-4} \mathrm{M}$. It should be pointed out that acid phosphatase extracted from a constitutive strain is likewise inhibited by $\mathrm{K}_{2} \mathrm{HPO}_{4}$. 


\section{Temperature inactivation}

An enzyme preparation was treated for $30 \mathrm{~min}$. at the temperature indicated on the abscissa in Fig. 6, and both acid and alkaline phosphatase activities were measured. Acid phosphatase is completely inactivated at $45^{\circ}$ at which temperature alkaline phosphatase is still completely active; inactivation of the latter is obtained only at $65^{\circ}$. According to Rothman \& Coleman (1968), alkaline phosphatase in crude extracts of Escherichia coli is even more heat-resistant than acid phosphatase from the same organism.

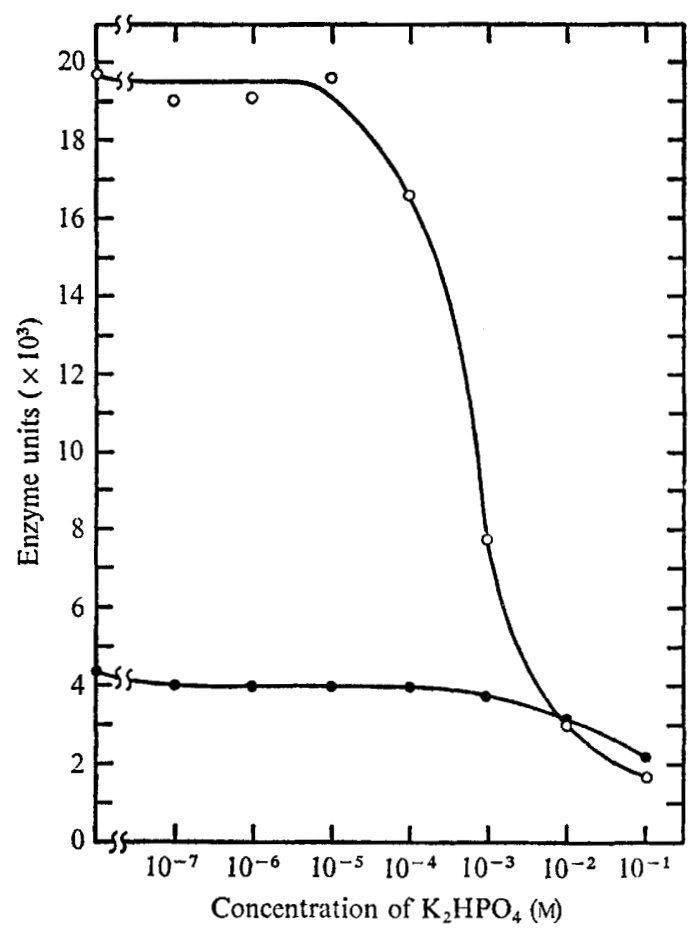

Fig. 4. Effect of phosphate on phosphatase activity. Acid phosphatase $(O)$ and alkaline phosphatase (๑) were assayed at increasing concentrations of $\mathrm{K}_{2} \mathrm{HPO}_{4}$.

\section{Inactivation by pronase}

A preparation of phosphatases was treated for various periods with pronase $\left(20 \mu \mathrm{g} . / \mathrm{ml}\right.$.) at $37^{\circ}$ before assaying enzyme activity (Fig. 7). It is evident that only acid phosphatase is sensitive to the proteolytic enzyme while alkaline phosphatase is practically unaffected. The alkaline phosphatase of Escherichia coli is similarly resistant to digestion by pronase whereas the acid phosphatase is sensitive (Rothman \& Coleman, 1968).

\section{Inactivation by chelating agents}

Escherichia coli alkaline phosphatase is a zinc metalloenzyme (Plocke, Levinthal \& Vallee, 1962; Simpson \& Vallee, 1969), and alkaline phosphatase from various other sources requires divalent cations for its activity (Dorn, 1968; Kaneko, 1968). Chelating agents, being metal-binding compounds, can therefore abolish the activity of this enzyme and its activity can be restored by replacement of the required metal ions. 
The effect of three chelating agents was tested on yeast phosphatase activity. An enzymically active supernatant was assayed with increasing concentrations of chelates (Fig. 8). All three chelating agents - EDTA (Fig. 8a), 1, I0-phenanthroline (Fig. 8b) and 8-hydroxyquinoline (Fig. $8 \mathrm{c}$ ) - specifically inhibit alkaline phosphatase activity and have either no effect (in the case of EDTA) or a relatively small effect on acid phosphatase. The inactivation kinetics of alkaline phosphatase by $10^{-2} \mathrm{M}$-EDTA is shown in Fig. 9; maximum inhibition of activity is obtained instantaneously after

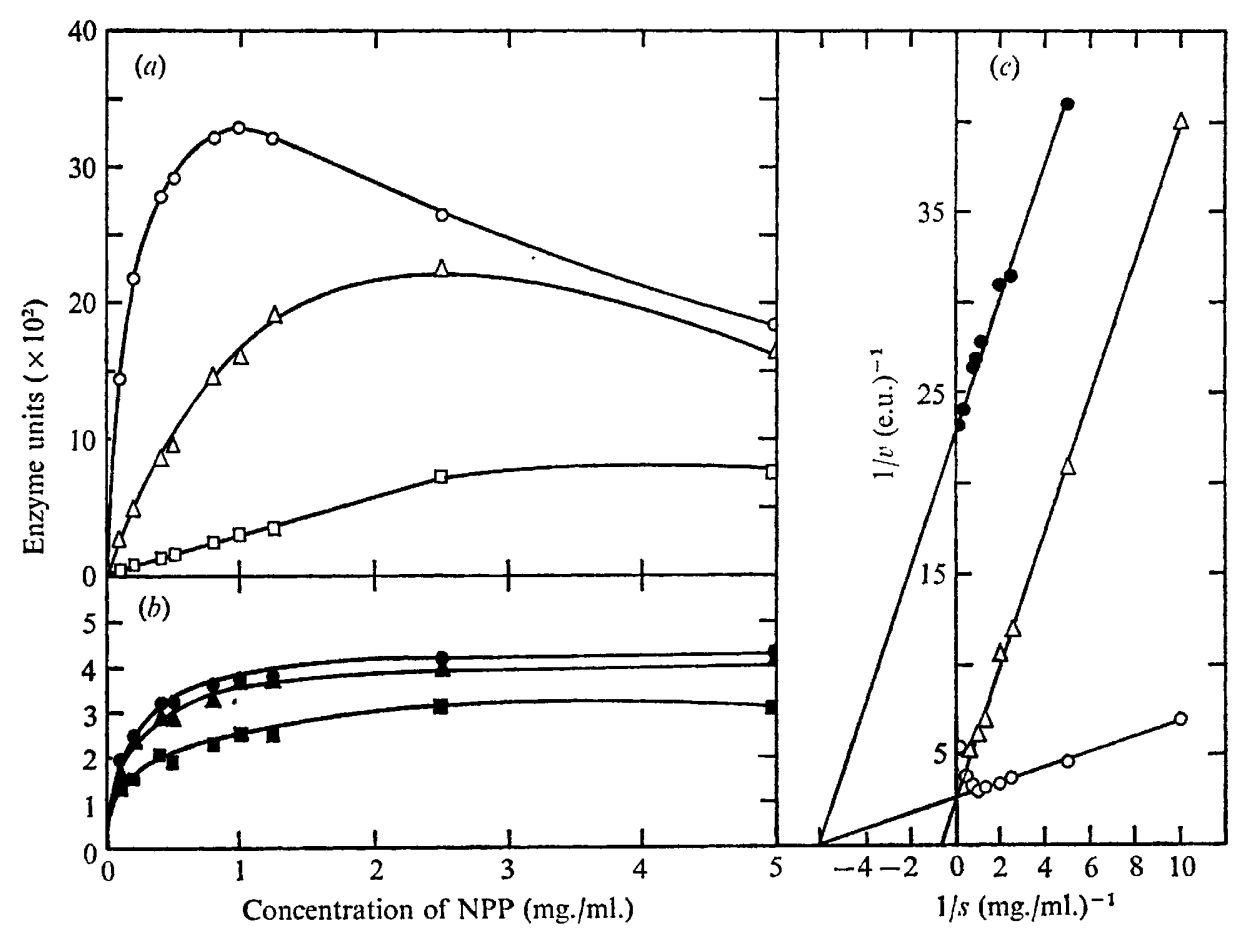

Fig. 5. Phosphatase activity as a function of substrate ( $p$-nitrophenyl phosphate) concentration at various phosphate concentrations. (a) Acid phosphatase; $(b)$ alkaline phosphatase; (c) Lineweaver-Burk plot of data from $(a)$ and $(b) \mathrm{O}, \boldsymbol{\theta}=$ no $\mathrm{K}_{2} \mathrm{HPO}_{4} ; \Delta, \Delta=10^{-3} \mathrm{M}-\mathrm{K}_{2} \mathrm{HPO}_{4}$; $\square, \mathbf{\square}=10^{-2} \mathrm{M}-\mathrm{K}_{2} \mathrm{HPO}_{4}$.

the addition of the chelate. Restoration of enzyme activity after the addition of increasing concentrations of either zinc or magnesium ions is shown in Fig. Io. While $\mathrm{Zn}^{2+}$ has very little effect, $\mathrm{Mg}^{2+}$ completely restores enzyme activity. The activity obtained with $\mathrm{IO}^{-3} \mathrm{M}-\mathrm{Mg}^{2+}$ is even higher than that of the original enzyme preparation extracted in tris buffer without $\mathrm{MgSO}_{4}$. These results clearly show that alkaline phosphatase of Saccharomyces cerevisiae requires magnesium ions for its activation whereas the activity of acid phosphatase is cation-independent.

\section{DISCUSSION}

Both acid and alkaline phosphatase of baker's yeast are regulated by the concentration of phosphate in the culture medium. After phosphate starvation these two enzymes are derepressed; the activity of acid phosphatase increases by a factor of about 10 and that of alkaline phosphatase by a factor of 4 . It is expected that the acid 


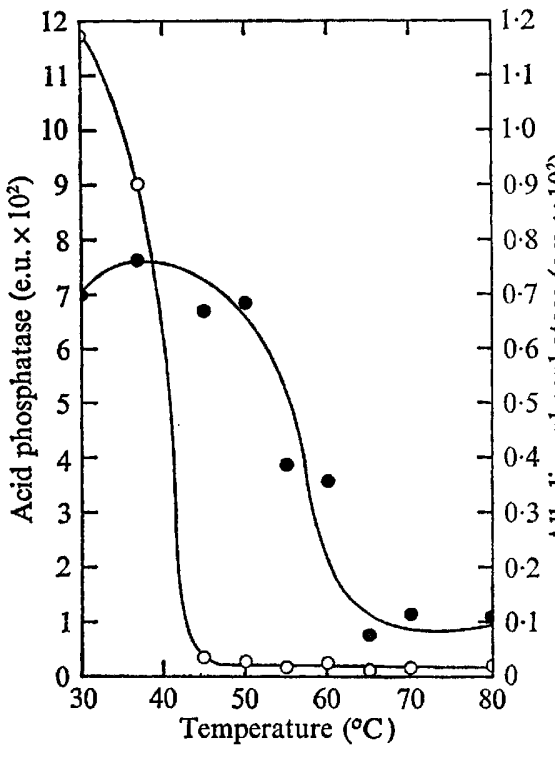

Fig. 6

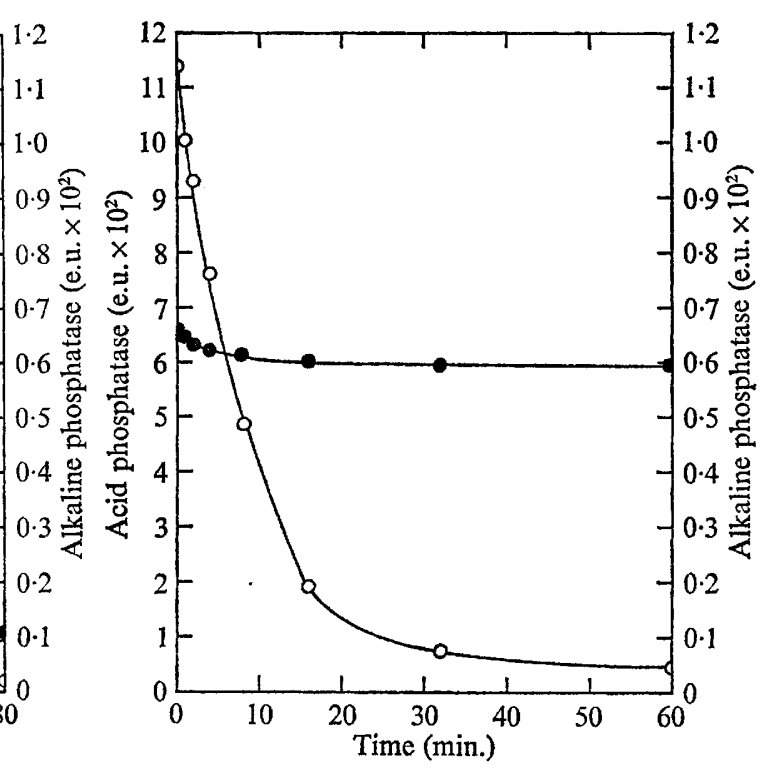

Fig. 7

Fig. 6. Effect of temperature on phosphatase activity. A mixed enzyme preparation was incubated for $30 \mathrm{~min}$. at the indicated temperatures, and acid phosphatase $(O)$ and alkaline phosphatase (0) assayed.

Fig. 7. Effect of digestion by pronase on phosphatase activity. Pronase $(20 \mu \mathrm{g} . / \mathrm{ml}$.) was added at time 0 to a mixed enzyme preparation which was incubated at $37^{\circ}$. At intervals samples were removed for the determination of acid phosphatase $(0)$ and alkaline phosphatase $(\bullet)$.

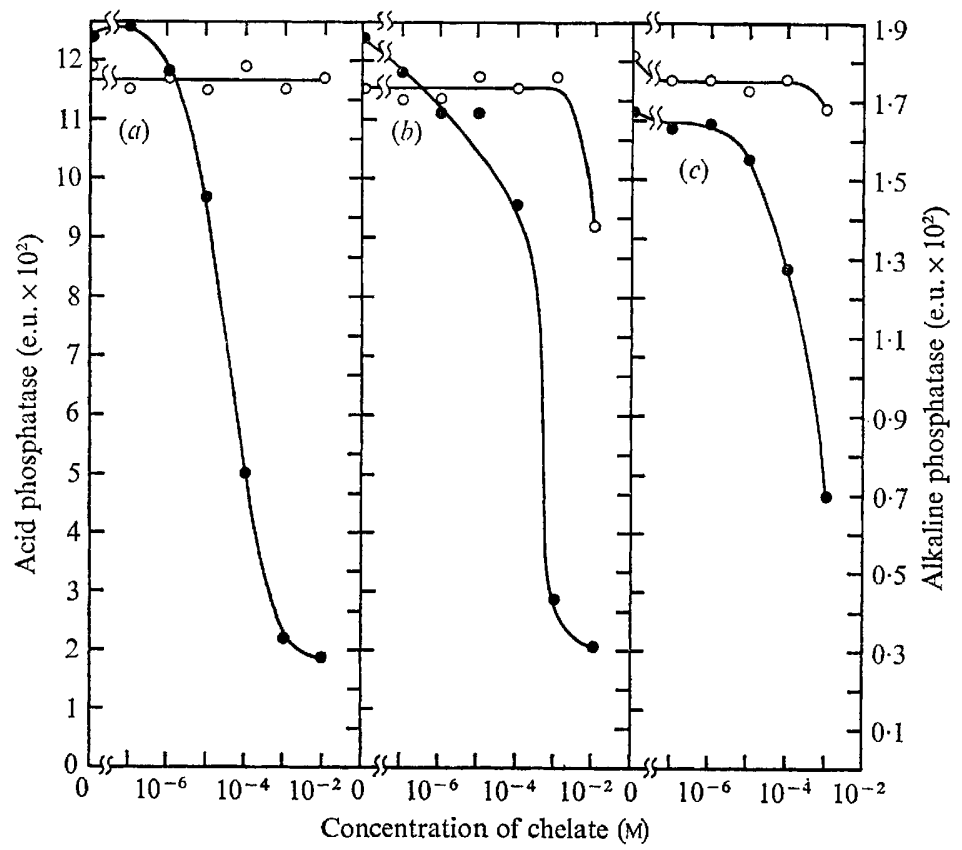

Fig. 8. Effect of chelating agents on phosphatase activity. Acid phosphatase $(O)$ and alkaline phosphatase ( $\bullet$ ) were assayed in a mixed enzyme preparation in the presence of various concentrations of the chelate. (a) Ethylene diaminetetraacetate (EDTA); (b) I, I0phenanthroline; (c) 8-hydroxyquinoline. 
phosphatase is the more important enzyme in the yeast cell since optimum growth is obtained at acid pH. Garen \& Levinthal (1960) and Blum (1965) have shown that derepression of phosphatases in Escherichia coli and Euglena gracilis is the result of de novo enzyme synthesis. It is reasonable to assume that this is also the case in yeast.

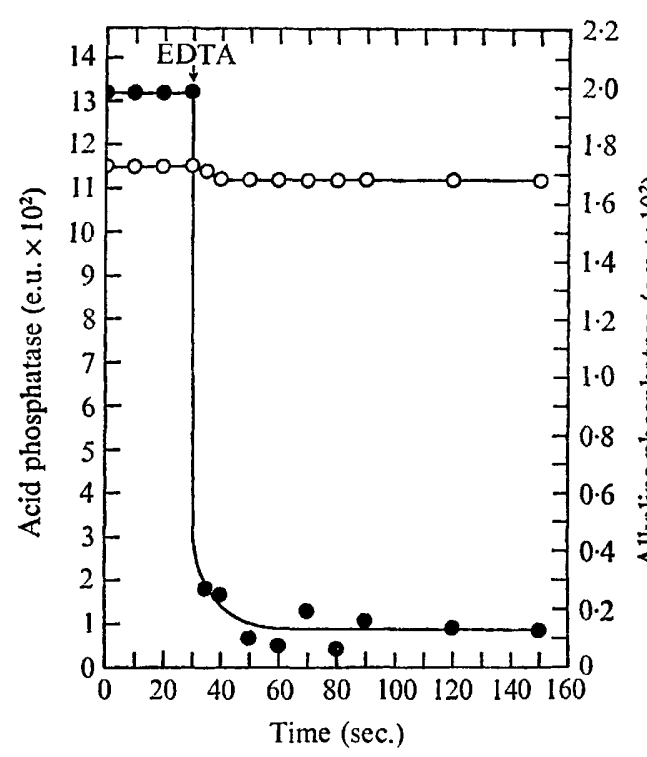

Fig. 9

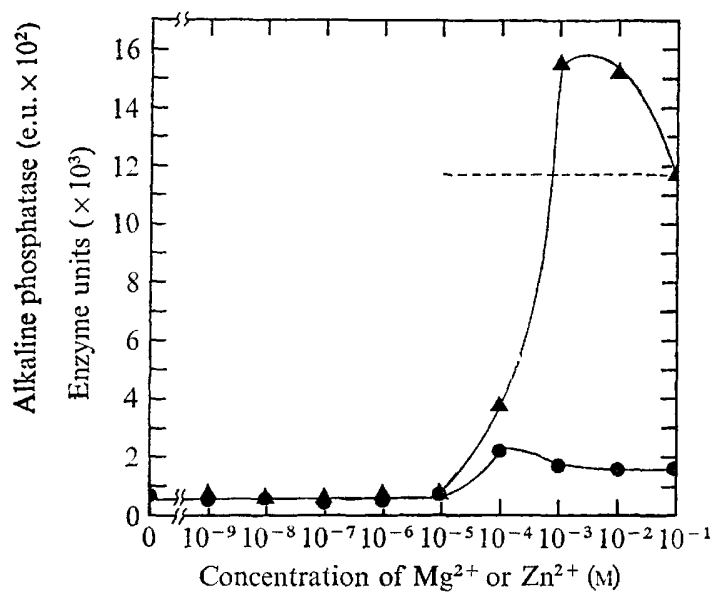

Fig. I0

Fig. 9. Kinetics of alkaline phosphatase inactivation by EDTA. A mixed enzyme preparation was assayed at short time intervals for acid $(O)$ and alkaline $(O)$ phosphatase; at 30 sec. EDTA was added to final concentration of $10^{-2} \mathrm{M}$.

Fig. IO. Effect of $\mathrm{Mg}^{2+}$ and $\mathrm{Zn}^{2+}$ on the activity of alkaline phosphatase inhibited by EDTA. The enzyme was prepared in tris buffer without $\mathrm{MgSO}_{4}$ and the activity of the preparation is shown by the broken line. It was treated with EDTA at a final concentration of $10^{-2} \mathrm{M}$ and assayed in the presence of increasing concentrations of either $\mathrm{MgSO}_{4}(\Delta)$ or $\mathrm{ZnSO}_{4}(\mathbf{(})$.

All structural or constitutive mutants isolated so far affect both acid and alkaline phosphatase simultaneously. It should be pointed out, however, that the mutants were isolated under the acidic conditions which are optimal for growth, so that enzyme activity observed during selection of the mutants was that of acid phosphatase. Dorn (1965) has similarly isolated mutants of Aspergillus lacking both enzymes, but he also found additional mutants which had lost the activity of each enzyme separately.

The two enzymes are non-specific monoesterases (Schmidt \& Laskowsky, 1961); nevertheless they seem to be very distinct enzymes. In addition to their different $\mathrm{pH}$ optima they are located differently in the organisms, react differently to inhibition by phosphate, to temperature inactivation, to digestive attack by pronase and to cation depletion. Furthermore, acid and alkaline phosphatases from several sources differ in their specificity for various substrates (Neumann, 1968). It is therefore surprising that constitutive and, in particular, structural mutations affect both enzymes simultaneously. Due to the relatively high mutation rate obtained $(\sim \mathrm{I} \%)$, it is unlikely that double mutants were selected. It is more plausible that both enzymes have a genetic regulatory mechanism and a genetic structure in common. They may either share a common polypeptide or one of the enzymes is a subunit of the other. 
We are indebted to R. K. Mortimer and G. Simchen for the yeast strains. The technical assistance of Mrs Nava Silberstein is gratefully acknowledged.

\section{REFERENCES}

Aono, H. \& OtsuJI, N. (1968). Genetic mapping of regulator gene phos for alkaline phosphatase in Escherichia coli. Journal of Bacteriology 95, I $182-1183$.

Bennun, A. \& Blum, J. J. (1960). Properties of the induced acid phosphatase and of the constitutive acid phosphatase of Euglena. Biochimica et biophysica acta 128, 106-123.

Blum, J. J. (1965). Observation on the acid phosphatases of Euglena gracilis. Journal of Cell Biology 24, $223-234$.

Boer, P. \& Steyn-Parvé, E. (I969). Some kinetic aspects of the mechanism of action of an acid phosphatase from baker's yeast (Saccharomyces cerevisiae). Biochimica et biophysica acta $\mathbf{1 7 \mathbf { I }}$, 360-362.

BRACHA, M. \& YAGIL, E. (1969). Genetic mapping of the phoR regulator gene of alkaline phosphatase in Escherichia coli. Journal of General Microbiology 59, 77-8I.

DorN, G. L. (1965). Genetic analysis of phosphatases in Aspergillus nidulans. Genetical Research (Cambridge) 6, 13-26.

DorN, G. L. (1968). Purification and characterization of phosphatase I from Aspergillus nidulans. Journal of Biological Chemistry 243, 3500-3506.

DoRN, G. L. \& Rivera, W. (1966). Kinetics of fungal growth and phosphatase formation in Aspergillus nidulans. Journal of Bacteriology 92, 1618-1622.

Echols, H., Garen, A., Garen, S. \& Torriani, A. (1961). Genetic control of repression of alkaline phosphatase in Escherichia coli. Journal of Molecular Biology 3, 425-438.

FAN, D. P. (1966). Decay of intact messengers in bacteria. Journal of Molecular Biology 16, I64-179.

Garen, A. \& Levinthal, C. (1960). A fine-structure genetic and chemical study of the enzyme alkaline phosphatase of E. coli. I. Purification and characterization of akaline phosphatase. Biochimica et biophysica acta $38,470-483$.

KANEKo, A. (1968). Studies on two types of alkaline phosphatase in rat liver. Journal of Biochemistry 64, 785-794.

KrTAZUME, Y., YČAS, M. \& VINCENT, W. S. (1962). Metabolic properties of a ribonucleic acid fraction in yeast. Proceedings of the National Academy of Sciences of the United States of America 48, 265-282.

Lindegren, G., Hwang, Y. L., Oshima, Y. \& Lindegren, C. L. (1965). Genetical mutants induced by ethyl methanesulfonate in Saccharomyces. Canadian Journal of Genetics and Cytology 7, 49I499.

MARKHAM, E. \& BYRNE, W. J. (I968). Uptake, storage and utilization of phosphate by yeast. III. The behaviour of phosphate-starved yeast. Journal of the Institute of Brewing 74, 374-378.

McLellan, W. L., Jun. \& Lampen, J. O. (1963). The acid phosphatase of yeast. Localization and secretion by protoplasts. Biochimica et biophysica acta 67, 324-326.

Monod, J., Pappenheimer, A. M., Jun. \& Cohen-Bazire, G. (I952). La cinétique de la biosynthèse de la $\beta$-galactosidase chez $E$. coli considérée comme fonction de la croissance. Biochimica et biophysica acta 9, 648-660.

Moses, V. (1967). The regulatory process in the derepression of enzyme synthesis. Alkaline phosphatase of Bacillus subtilis. Biochemical Journal ro3, 650-659.

NeumanN, H. (1968). Substrate selectivity in the action of alkaline and acid phosphatases. Journal of Biological Chemistry 243, 4671-4676.

NyC, J. F., KAdNer, R. J. \& Crocken, B. J. (I966). A repressible alkaline phosphatase in Neurospora crassa. Journal of Biological Chemistry 24I, I468-I477.

Plocke, D. J., LeVINTHAL, C. \& VAlleE, B. L. (I962). Alkaline phosphatase of Escherichia coli: A zinc metalloenzyme. Biochemistry I, 373-378.

RAUTANEN, N. \& KäRKKÄINEN, V. (1951). On the phosphatase activity of low-phosphorus Torulopsis utilis. Acta chimica scandinavica 5, 1216-1217.

Rothman, F. \& Coleman, J. R. (1968). Kinetics of transcription and translation of a repressed gene. Journal of Molecular Biology 33, 527-53I. 
Schmidt, G., Bartsch, G., Lamont, M. C., Herman, T. \& Liss, M. (1963). Acid phosphatase of baker's yeast: An enzyme of the external cell surface. Biochemistry 2, 126-131.

Schmidt, G. \& Laskowski, M., Sen. (196r). Phosphate ester cleavage (Survey). In The Enzymes, vol. 5, pp. 3-35. Edited by P. D. Boyer, H. Lardy \& K. Myrback. New York: Academic Press.

SHIEH, T. R. WODZINSKI, R. J. \& WARE, J. H. (1969). Regulation of the formation of acid phosphatases by inorganic phosphate in Aspergillus ficuum. Journal of Bacteriology 100, I161-I 165.

Simpson, R. T. \& ValleE, B. L. (I969). Zinc cobalt alkaline phosphatases. Annals of the New York Academy of Sciences $\mathbf{1 6 6 , 6 7 0 - 6 9 5 .}$

Suomalainen, H., Linko, M. \& OuRA, E. (1960). Changes in the phosphatase activity of baker's yeast during the growth phase and location of the phosphatases in the yeast cell. Biochimica et biophysica acta 37, 482-490.

Tonino, G. J. M. \& STEYN-PARVÉ, E. P. (I963). Localization of some phosphatases in yeast. Biochimica et biophysica acta 67, 453-469.

TORRIANI, A. (1960). Influence of inorganic phosphate in the formation of phosphatases by Escherichia coli. Biochimica et biophysica acta 38, 460-469. 